\title{
KVANTIFIKACE SÍLY HRANIČNÍHO EFEKTU NA HRANICÍCH LIBERECKÉHO KRAJE
}

\author{
Emil Drápela, Jan Bašta
}

\begin{abstract}
The article describes the method of quantifying the border effect using the gravity model of spatial interactions. As input data used in the model were the number of inhabitants of the villages, the distance between them in meters, and the average daily traffic flow on the roads. By comparing the expected spatial interaction (the result of the gravity model) and the real spatial interaction (real traffic on the road), the power of border effect was calculated. The article compared the strength of border effect on the border with Germany, Poland and other Czech regions. The results showed that the negative effect of border effect is indeed greater at state borders, but not much, because many years of cross-border cooperation in the region and entry to the Schengen area helped to mitigate the negative effects considerably.
\end{abstract}

Keywords: spatial interactions, gravity model, border effect, cross-border cooperation, transport geography, Liberec region

\section{Úvod}

Liberecký kraj je pohraniční region v České republice, sousedící s Německem a Polskem. Průběh státní hranice je přitom velmi členitý, vytvářející na české straně Frýdlantský výběžek (a Šluknovský v sousedním Ústeckém kraji), na polské straně výběžek Bogatyňský a na německé straně výběžek Žitavských hor (Zittauer Gebirge). Řada oblastí tak vzhledem ke své periferní poloze vůči centrům zaostává v sociální a ekonomické oblasti, $\mathrm{k}$ čemuž dlouhá léta přispíval i silný hraniční efekt $\mathrm{z}$ důvodu malé propustnosti hranic. Po změně politických režimů v letech 1989-90 se i režim na hranicích uvolnil a začala být aktuální potřeba přeshraniční spolupráce. Ta vyvrcholila $\mathrm{v}$ roce 1991 vyhlášením trilaterálního Euroregionu Nisa - Neisse - Nysa, který byl vůbec prvním euroregionem v oblasti střední a východní Evropy. Dalším pokrokem pak byl vstup Česka a Polska do Schengenského prostoru v roce 2007, jehož výsledkem bylo zrušení hraničních kontrol.

Mohlo by se tedy zdát, že po 27 letech intenzivní přeshraniční spolupráce a 11 letech od vstupu do Schengenského prostoru by negativní hraniční efekt měl být minimalizován, či dokonce vymizet. Proti tomu však hovoří jazyková rozmanitost oblasti a relativně malá jazyková vybavenost obyvatel příhraničí. Abychom tedy zjistili, jak silný hraniční efekt ve skutečnosti je, pokusili jsme se ho kvantifikovat 
pomocí gravitačního modelu prostorových interakcí, výsledky pak prezentujeme v tomto článku. Ústřední hypotézou pak je předpoklad, že hraniční efekt na státní hranici bude silnější než na hranici mezi českými kraji, přičemž se bude projevovat nižší relativní intenzitou prostorových interakcí vůči interakcím očekávaným.

\section{Teoreticko-metodická východiska}

Gravitační model prostorových interakcí je jedním ze základních druhů geografických modelů, využívaných často $\mathrm{k}$ různým druhům analýz. Model využíá klasického Newtonova vzorce, přičemž jej pro různé druhy úloh obohacuje kalibračními koeficienty, které jeho využití významně rozšiřují. Gravitační model tak může sloužit k odhalení role geografických bariér na obchod (Eaton a Kortum, 2002), odhalení síly hraničního efektu na obchod se zemědělskými produkty (Olper a Raimondi, 2008), analýzu mezinárodního obchodu ve státech Evropské unie (Nitsch, 2000) mezinárodních migračních toků (DeWaard, Kim a Raymer, 2012), či přeshraničních kapitálových tokủ (Portes a Rey, 2005).

Ve své základní formě je model definován pouze funkcí mas dvou bodů, vzdálenosti mezi nimi a kalibračním koeficientem (Marshall, 2016):

$$
F_{i j}=k \frac{P_{i} P_{j}}{d_{i j}}
$$

kde, $F_{i j}$ je síla očekávané prostorové interakce mezi body $i$ a $j, P_{i}$ a $P_{j}$ jsou velikosti mas bodů $i$ a $j, d_{i j}$ je vzdálenost mezi body $i$ a $j$ a $k$ je kalibrační koeficient. Pro kvantifikaci hraničního efektu $\mathrm{v}$ tomto článku byly pro velikosti mas použity počty obyvatel jednotlivých měst a obcí z průběžné evidence obyvatel (pro rok 2017), vzdálenost byla vyjádřena Euklidovskou vzdáleností v metrech a jako kalibrační koeficient bylo využito bezrozměrné číslo 0,007245 , které pro účely operací na úrovni mezoregionů v České republice doporučuje ve své práci Drápela (2017). Tento kalibrační koeficient byl zkonstruován na základě nalezení podobností v intenzitě prostorových interakcí mezi krajskými městy v ČR, jde však stále pouze o orientační vyjádření očekávané prostorové interakce.

Samotnou intenzitu prostorových interakcí $\left(I_{i j}\right)$ pak lze definovat jako relativní vyjádření poměru prostorové interakce reálné $\left(C_{i j}\right)$ vůči prostorové interakci očekávané (Drápela, 2017):

$$
I_{i j}=\frac{C_{i j}}{F_{i j}}
$$


Reálná prostorová interakce $\left(C_{i j}\right)$ je pak vyjádřena průměrnou denní intenzitou provozu na úseku silnice, procházejícím vybranou částí hranice. Úseky, kde se hraniční efekt projevuje s vyšší intenzitou, budou dosahovat hodnot méně než 1 , naopak úseky, kde reálné prostorové interakce převyšují očekávané, budou dosahovat hodnot vyšších než 1 .

Vzhledem $\mathrm{k}$ faktu, že jednotlivé úseky přeshraničních silnic nejsou samotnými body, z jejichž mas se hodnota interakce počítá (to jsou města a obce v okolí), bylo vždy nutné najít všechny dvojice obcí, u kterých hodnota očekávané interakce dosáhne alespoň 1 (tedy vyprodukuje alespoň 1 vozidlo denně) a nejrychlejší cesta mezi nimi (zjištováno na serveru mapy.cz) vede přes analyzovaný úsek. Součet všech těchto interakcí dal dohromady celkovou očekávanou interakci $\left(F_{i j}\right)$. Počet těchto dvojic byl v řádech desítek, u nejvytíženějších úseků $\mathrm{i}$ více než 100 . Vzhledem k významnosti silničních komunikací v Libereckém kraji, z nichž žádná není významným mezinárodním koridorem, byla dále stanovena hranice max. $150 \mathrm{~km}$ od analyzovaného místa, za níž ležící obce již nebyly do analýzy vkládány. Tento krok byl vložen z důvodu zamezení vkladu nereálných interakcí s vzdálenými mnohamilionovými aglomeracemi, které by však nejspíše nebyly realizovány automobilovou dopravou.

Vstupní data pro průměrné denní intenzity provozu byla získána vlastním měřením, které probíhalo trojím způsobem: jednak to bylo (a) ruční měření, kdy sčítač zaznamenával počty a druh vozidel v hodinových časových úsecích; (b) analýzy videozáznamu, probíhající prakticky stejně jako u ručního měření, avšak s výhodou, že záznam je možné zrychlit a sčítání tak zefektivnit; a (c) sčítání pomocí statistického radaru, které poskytlo údaje i pro přepočty dat $\mathrm{z}$ ostatních druhů měření.

Pro úlohu byl použit statistický radar Sierzega SR4, který byl na lokalitě nainstalován po dobu zhruba 7-14 dnů, přičemž kontinuálně snímal průjezdy veškerých vozidel. Data poté byla zpracována v softwaru Sierzega SRA, kde po očištění a klasifikaci druhů vozidel bylo možné zpracovat průměrný denní průběh intenzity provozu na daném úseku silnice. Ten pak byl využit jako kalibrační křivka pro úseky, které svým denním průběhem intenzity provozu korelovaly s tímto úsekem, avšak nebyla pro ně dostupná data pro celé období 0-24 hodin (typicky všechny ručně měřené úseky). Př́i přepočtech pak bylo nutné zohlednit den $\mathrm{v}$ týdnu, ve který měření probíhalo, a podobnost v geografické poloze a $\mathrm{v}$ hierarchii systému pozemních komunikací. Bylo identifikováno několik variet $\mathrm{v}$ denním průběhu intenzity provozu, tomuto problému se však dostatečně věnuje odborná literatura (např. Ha, 2014).

\section{Výsledky}

Výsledné hodnoty intenzity prostorových interakcí jsme rozdělili na hranici Libereckého kraje s Německem, Polskem a dalšími českými kraji. Jednotlivé 
sledované úseky jsou seřazeny do tabulek (tab. 1-3) podle jejich geografické polohy, vždy od západu $\mathrm{k}$ východu. Na hranici s Německem byly do šetření přidány i hraniční přechody Varnsdorf-Seifhennersdorf a Varnsdorf-Großschönau, nacházející se již v Ústeckém kraji, nebot' jsou důležité z hlediska interpretace dat. Úseky z Hrádku nad Nisou do Žitavy (Zittau) jsou přiřazeny k německé hranici, ačkoli se technicky jedná o hranici s Polskem, přes které se cca. $3 \mathrm{~km}$ projíždí.

Tab. 1: Intenzita prostorových interakcí na hranici Libereckého kraje s Německem Table 1: Intensity of spatial interactions on the border of the Liberec region with Germany

\begin{tabular}{|l|c|r|r|r|}
\hline \multicolumn{1}{|c|}{ Měřený úsek } & Silnice & \multicolumn{1}{c|}{$\mathbf{F}_{\mathbf{i j}}$} & \multicolumn{1}{c|}{$\mathbf{C}_{\mathbf{i j}}$} & \multicolumn{1}{c|}{$\mathbf{I}_{\mathbf{i j}}$} \\
\hline Varnsdorf-Seifhennersdorf & II/265 & 1799,8 & 2657 & $\mathbf{1 , 4 7 6}$ \\
\hline Varnsdorf-Großschönau & II/264 & 1348,6 & 2751 & $\mathbf{2 , 0 4 0}$ \\
\hline Petrovice-Lückendorf & II/270 & 971,3 & 656 & $\mathbf{0 , 6 7 5}$ \\
\hline Hrádek nad Nisou-Zittau & 35J & 1708,9 & 3422 & $\mathbf{2 , 0 0 2}$ \\
\hline Hrádek nad Nisou-Zittau & I/35 & 11544,8 & 6185 & $\mathbf{0 , 5 3 6}$ \\
\hline
\end{tabular}

Z výsledků uvedených v tab. 1 vyplývá, že mezi jednotlivými sledovanými úseky jsou velké rozdíly. Zatímco u lokalit Petrovice-Lückendorf a Hrádek nad Nisou-Zittau (I/35) jsou hodnoty intenzit hluboko pod očekávanými hodnotami, u lokalit Varnsdorf-Großschönau a Hrádek nad Nisou-Zittau (35J) jsou reálné hodnoty dvojnásobné oproti očekávaným. K vysvětlení této situace je nutné znát některé místní reálie a data o dojížd'ce do zaměstnání a do škol.

$\mathrm{Z}$ dat o dojížd'ce ze Sčítání lidu, domů a bytů v roce 2011 lze vyčíst, že podstatná část Šluknovského výběžku, nevyjímaje největší města Varnsdorf, Rumburk a Šluknov, spáduje nikoli do okresního města Děčína, či krajského města Ústí nad Labem, ale do Liberce. Nejkratší a nejrychlejší cesta přitom nevede přes území Česka, ale přes Německo. Obyvatelé Šluknovského výběžku této zkratky často využívají při svých cestách automobilem, ale i vlakem. Na druhou stranu, objem této dojížd'ky netvoří ani $50 \%$ z celkové intenzity dopravy, což se potvrdilo i při měření na úseku Hrádek nad Nisou-Zittau (I/35), který jednak dosahuje pouze 53,6 \% očekávané hodnoty, dále pak při ručním měření na tomto úseku jsme zjistili, že podíl automobilů z Ústeckého kraje je zhruba 1/3 (objem dojížd'ky lze samozřejmě zjistit i z dat ze Sčítání lidu, avšak tato data jsou z roku 2011 a tedy poněkud zastaralá). Vnitrostátní dojížd’ka za prací a do škol, realizovaná přes území Německa, je tedy podstatným, nikoli však klíčovým důvodem, proč na úsecích z města Varnsdorf dosahují intenzity prostorových interakcí dvojnásobných hodnot oproti předpokladu.

Druhou lokalitou, kde hodnoty intenzity prostorových interakcí dosáhly hodnoty 2, je místní komunikace 35J mezi Hrádkem nad Nisou a Žitavou. Vysoké 
hodnoty na tomto úseku nemohou být vysvětleny dojižd'kou, nebot' z dat plyne, že se zde jedná maximálně o desítky, nikoli však potřebné stovky až tisíce obyvatel. Vysvětlení tkví v oblíbenosti německých obchodů u českých zákazníků. Vzhledem k malým vzdálenostem, př́źznivé cenové politice, poněkud odlišné nabídce a v některých případech i vyšší kvalitě produktů jsou německé supermarkety častým cílem cest českých obyvatel príhraničí. Tuto skutečnost pak lze doložit observacemi z parkovišt' supermarketů, kdy zejména o víkendu Češi mohou tvořit až více než 50 \% všech zákazníků. Podobná situace pak je i v oblasti Varnsdorfu, kdy obce Rumburk, Seifhennersdorf, Varnsdorf a Großschönau prakticky tvoří jedinou městskou aglomeraci a přeshraniční cesty za obchodem či službami jsou zde velmi časté.

Jak si naopak vysvětlit nízké hodnoty intenzity prostorových interakcí u silnice I/35, která je nejfrekventovanější komunikací v oblasti? Zde je nutné si uvědomit, že tato silnice je nejkratší spojnicí mezi obcemi velké části Libereckého a části Královéhradeckého kraje s velkými německými městy, jako jsou např. Drážd'any (Dresden), Lipsko (Leipzig), Berlín (Berlin), nebo naopak spojnicí lužických měst $\mathrm{s}$ Prahou. Gravitační model v tomto případě vygeneruje relativně vysokou hodnotu očekávané interakce, která však v reálu je výrazně ztlumena hraničním efektem.

Tab. 2: Intenzita prostorových interakcí na hranici Libereckého kraje s Polskem Table 2: Intensity of spatial interactions on the border of Liberec region with Poland

\begin{tabular}{|l|c|c|r|c|}
\hline \multicolumn{1}{|c|}{ Měřený úsek } & Silnice & \multicolumn{1}{c|}{$\mathbf{F}_{\mathbf{i j}}$} & \multicolumn{1}{c|}{$\mathbf{C}_{\mathbf{i j}}$} & \multicolumn{1}{c|}{$\mathbf{I}_{\mathbf{i j}}$} \\
\hline Frýdlant-Bogatynia & 3511 & 827,2 & 558 & $\mathbf{0 , 6 7 5}$ \\
\hline Habartice-Zawidów & $\mathrm{I} / 13$ & 3368,6 & 2244 & $\mathbf{0 , 6 6 6}$ \\
\hline Nové Město p. S.-Świeradów-Zdrój & $\mathrm{II} / 291$ & 1197,7 & 823 & $\mathbf{0 , 6 8 7}$ \\
\hline Harrachov-Szklarska Poreba & $\mathrm{I} / 10$ & 15966,9 & 1894 & $\mathbf{0 , 1 1 9}$ \\
\hline
\end{tabular}

Situaci na česko-polské hranici dokládá tab. 2. Sledovány byly celkem 4 lokality, z nichž první tři se nacházejí ve Frýdlantském výběžku, čtvrtou lokalitou je pak sedlo oddělující Jizerské hory od Krkonoš. Na žádné z lokalit nedošlo k překročení hodnoty intenzity prostorových interakcí 1 , ve Frýdlantském výběžku se hodnoty pohybují v rozmezí 0,6 - 0,7, v Harrachově pak lehce přesahují 0,1 .

Velmi nízká hodnota u harrachovské silnice I/10 jasně dokladuje velmi silné působení hraničního efektu v této lokalitě. Silnice by měla sloužit jako spojnice mezi Prahou, zhruba osmdesátitisícovou Jelení Horou (Jelenia Góra) a zhruba stotisícovou Lehnicí (Legnica). Přestože vzdálenost mezi městy nejsou velké (vzdálenost Praha-Jelení Hora je srovnatelná např. se vzdáleností Praha-České Budějovice, vzdálenost Praha-Lehnice pak se vzdáleností Praha-Mohelnice), míra reálně generovaných prostorových interakcí je velmi nízká, a to ze dvou důvodů: 
prvním důvodem je vysoká deviatilita komunikace, plynoucí z jejího trasování v náročném horském terénu. Dalším důvodem je nedostatečná maximální povolená rychlost, která výrazně limituje využití této komunikace pro delší cesty. Komunikace prochází horskými údolími, v nichž se nachází řada obcí, po většinu cesty v úseku Jablonec nad Nisou - Jelení Hora je tedy rychlost omezena na 50 $\mathrm{km} / \mathrm{h}$. Silnice I/10 tak nesplňuje nároky kladené na páteřní komunikace spojující regionální centra, což přispívá k působení hraničního efektu na této části hranice.

Harrachovskou silnici I/10 lze srovnávat se silnicí I/13 v úseku HabarticeZawidów. I v tomto př́ípadě jde o spojnici českého vnitrozemí a blízkých polských měst, jako Zhořelec (Zgorzelec), Boleslav (Bolesławiec) a Lubáň (Lubań); díky nižší deviatilitě komunikace, vyšší průměrné rychlosti a lepšímu napojení na polskou dálnici A4 se zde však hraniční efekt projevuje s nižší intenzitou. Pro všechny úseky ve Frýdlantském výběžku je pak charakteristický i přeshraniční pohyb za obchodem a službami, který se však projevuje s nižší intenzitou, než je tomu $u$ dříve zmiňovaných německých úseků. To je způsobeno faktem, že z velkých měst na české straně je bližze do Žitavy než do Polska. Navíc při silnici 35J (resp. v Polsku jde o silnici 2364D) se na polském území také nachází různé obchody, čerpací stanice, supermarket aj.

Podobně jako se na trase Varnsdorf - Hrádek nad Nisou projevuje vnitrostátní mobilita přes území Německa, existuje analogická situace u trasy Bogatyně (Bogatynia) - Świeradów-Zdrój, resp. Mirsk, intenzita tohoto pohybu je však podstatně slabší, nebot' Bogatyně z hlediska zaměstnanosti je z podstatné části soběstačná a co se týká služeb, spáduje spíše do Zhořelce.

Tab. 3: Intenzita prostorových interakcí na hranici Libereckého kraje s jinými českými kraji

Table 3: Intensity of spatial interactions on the border of the Liberec region with other Czech regions

\begin{tabular}{|l|c|r|r|r|}
\hline \multicolumn{1}{|c|}{ Měřený úsek } & Silnice & \multicolumn{1}{c|}{$\mathbf{F}_{\mathbf{i j}}$} & \multicolumn{1}{c|}{$\mathbf{C}_{\mathbf{i j}}$} & \multicolumn{1}{c|}{$\mathbf{I}_{\mathbf{i j}}$} \\
\hline Nový Bor-Česká Kamenice & $\mathrm{I} / 13$ & 6247,2 & 5562 & $\mathbf{0 , 8 9 0}$ \\
\hline Kravaře-Úštěk & $\mathrm{I} / 15$ & 4389,4 & 3828 & $\mathbf{0 , 8 7 2}$ \\
\hline Dubá-Mělník & $\mathrm{I} / 9$ & 7370,6 & 3974 & $\mathbf{0 , 5 3 9}$ \\
\hline Doksy-Mladá Boleslav & \multicolumn{1}{c}{$\mathrm{I} / 38$} & 8108,9 & 7189 & $\mathbf{0 , 8 8 7}$ \\
\hline Turnov-Mnichovo Hradišť̌ & $\mathrm{D} 10$ & 21583,7 & 21610 & $\mathbf{1 , 0 0 1}$ \\
\hline Turnov-Jičín & $\mathrm{I} / 35$ & 8578,9 & 7535 & $\mathbf{0 , 8 7 8}$ \\
\hline Jilemnice-Vrchlabí & $\mathrm{I} / 14$ & 6917,2 & 7263 & $\mathbf{1 , 0 5 0}$ \\
\hline
\end{tabular}

V tab. 3 je uvedena intenzita prostorových interakcí na úsecích komunikací, které vedou z Libereckého kraje do krajů sousedních. Z výsledků vyplývá, že 
hodnoty u 4 ze 7 sledovaných úseků se blíží 0,9 ; tuto hodnotu bychom tedy mohli považovat za střední zhlediska porovnání se státní hranicí. Úsek TurnovMnichovo Hradiště byl jedním ze tř́ úseků, podle kterých byl vypočítán kalibrační koeficient $k$, proto se jen nepatrně odchyluje od hodnoty 1 . Nejvyšší hodnoty intenzity prostorových interakcí dosahuje úsek Jilemnice-Vrchlabí, to je způsobeno relativně vyšší intenzitou pracovní dojížd'ky do Vrchlabí a oblasti Krkonoš obecně.

Naopak nejnižší hodnoty dosáhl úsek Dubá-Mělník, tento výsledek je však nutné brát s rezervou, nebot' naráží na limity použité metody. U některých obcí na Českolipsku totiž existují pro cesty do Prahy dvě zhruba stejně rychlé cesty: přes Dubou a Mělník, nebo přes Mladou Boleslav a po dálnici D10. Pro obec Doksy tak např. cesta přes Dubou trvá 1:10 h, zatímco přes Mladou Boleslav 1:11 h. $\mathrm{Z}$ důvodu konzistence metody tedy dvojice obcí Doksy-Praha byla zařazena do výpočtu očekávané prostorové interakce $\left(F_{i j}\right)$, protože jde o rychlejší cestu. $\mathrm{Na}$ druhou stranu však metoda není schopna jakkoli podchytit reálné cestovní preference obyvatel, odrážející i komfort cestování, který nejspíše bude vyšší po trase, jejíž podstatnou část tvoří dálnice D10. S vědomím tohoto omezení je pak nutné nahlížet i na tento výsledek.

Výsledky, publikované v tomto článku, je zajímavé porovnat s naší dřívější studií (Drápela a Kárníková, 2018), ve které bylo využito jako zdroj dat Sčítání dopravy z roku 2016. U většiny sledovaných úseků, které byly analyzovány v obou studiích, jsou výsledky přes odlišný zdroj dat obdobné, výrazné rozdíly jsou pouze dva, a to: (a) u úseku Harrachov-Szklarska Poreba (kde ve starší práci je hodnota $I_{i j}$ dokonce pouze 0.069 ), kde vzhledem k výrazně odlišné hodnotě průměrné denní intenzity provozu vůči sčítáním dopravy z let 2005 a 2010 i hodnotám z polských sčítání jde nejspíše o chybnou hodnotu, příp. hodnotu ovlivněnou nestandardními podmínkami v lokalitě v době sčítání; a (b) u úseku Frýdlant-Bogatynia, kde z důvodu chybějící hodnoty z českého sčítání dopravy byla použita hodnota ze sčítání polského, které však nejspíše bylo realizováno na křižovatce silnic Pocztowa a Aleja Solidarności, kde tento údaj byl značně ovlivněn vnitroobecní mobilitou. Vlastní měření tak pomohlo tyto chyby napravit.

\section{Závěr}

Hlavní výzkumná hypotéza, že hraniční efekt na státní hranici bude silnější než na hranici mezi českými kraji a bude se projevovat nižší relativní intenzitou prostorových interakcí vưči interakcím očekávaným, se s výjimkou třech úseků na česko-německé hranici, které se vyznačují intenzivní dojížd'kou za obchodem a službami a realizací vnitrostátních cest přes území Německa, potvrdila. Intenzita hraničního efektu na státní hranici však není drasticky větší; hodnoty indikátoru „intenzita prostorových interakci““ se u hranic s ostatními kraji pohybují obvykle kolem hodnoty 0,9, zatímco u státní hranice mezi 0,6-0,7. Lze tedy konstatovat, že hraniční efekt se stále projevuje s vyšší intenzitou na hranici státní než krajské, 
avšak jeho negativní působení se podařilo do velké míry utlumit.

Výjimkou však je úsek Harrachov-Szklarska Poreba na silnici I/10, kde se hraniční efekt projevuje velmi silně. Důvodem jsou fyzickogeografické poměry v oblasti a nedostatečná kvalita silnice, která by měla být jednou z hlavních přeshraničních komunikací a spojovat Prahu s regionálními centry v Polsku. Tato funkce komunikace však není naplněna.

Závěrem došlo k porovnání výsledků s předchozí studií, která však využívala dat ze sčítání dopravy, která v některých př́ípadech byla zavádějící. Bylo konstatováno, že metodika využívající vlastní měření poskytuje věrohodnější výsledky a pro použití v praxi je tak výhodnější. Celkově lze říci, že využití gravitačního modelu pro kvantifikaci hraničního efektu na hranici mezoregionů v místech, kde data nejsou zkreslena každodenní dojížd’kou do zaměstnání a škol (tedy na hranicích dojižd'kových regionů), lze doporučit.

\section{Poděkování}

Př́spěvek byl zpracovaný diky projektu SGS-FP-TUL 10/2017 „Kvantifikace border efektu pomocí geografických modeli̊ prostorových interakci“".

\section{Literatura}

DEWAARD, J. - KIM K. - RAYMER J. 2012. Migration Systems in Europe: Evidence from Harmonized Flow Data. In Demography. ISSN 0070-3370, 2012, vol. 49, no. 4, pp. 1307-1333.

DRÁPELA, E. 2017. Quantification of border effect on different types of borders: case study of the Czech Republic. In International Multidisciplinary Scientific GeoConference. Albena: SGEM, 2017, 17(53). ISBN 978-619-7408-10-2, pp. 687-693.

DRÁPELA, E. - KÁRNÍKOVÁ N. 2018. Methodological issues of using the gravity model to determine the power of border effect. In 25th Central European Conference on Useful Geography: Transfer from Research to Practice. Brno: Masarykova univerzita, 2018. ISBN 978-80-210-8907-5, pp. 367-375.

EATON, J. - KORTUM S. 2002. Technology, Geography, and Trade. In Econometrica. ISSN 0012-9682, 2002, vol. 70, no. 5, pp. 1741-1779.

HA, J. A. 2014. A Study on Methods to Calculate the Coefficient of Variance in Daily Traffic According to the Change in Hourly Traffic Volume. In Journal of Emerging Trends in Computing and Information Sciences. ISSN 2079-8407, 2014, vol. 5, no. 11, pp. 835-839.

MARSHALL, A. 2016. Quantitative Modelling in Human Geography. In Clifford N. et al. (eds.) Key Methods in Geography. 3rd ed. London: Sage, 2016. ISBN 978-1-4462-9860-2, pp. 302-322. 
NITSCH V. 2000. National borders and international trade: evidence from the European Union. In Canadian Journal of Economics/Revue canadienne d'économique. ISSN 0008-4085, 2000, vol. 33, no. 4, pp. 1091-1105.

OLPER A. - RAIMONDI V. 2008. Agricultural market integration in the OECD: A gravity-border effect approach. In Food Policy. ISSN 0306-9192, 2008, vol. 33, no. 2, pp. 165-175.

PORTES, R. - REY H. 2005. The determinants of cross-border equity flows. In Journal of International Economics. ISSN 0022-1996, 2005, vol. 65, no. 2, pp. 269-296.

\section{QUANTIFYING THE POWER OF BORDER EFFECT ON LIBEREC REGION BORDERS}

\section{Summary}

The aim of the article was to quantify the power of border effect on the borders of the Liberec region. The main hypothesis was that the border effect would be manifested with higher intensity at the state border with Germany and Poland than at the border with other Czech regions.

Gravity model was used to quantify the border effect. As input data used in the model were the number of inhabitants of the villages, the distance between them in meters, and the average daily traffic flow on the roads. The model was calibrated using a coefficient $k=0,007245$ that recommends Drápela (2017). By comparing the expected spatial interaction (the result of the gravity model) and the real spatial interaction (real traffic on the road), the power of border effect was calculated. The indicator is called "Intensity of spatial interactions" and with the increasing power of the border effect reaches lower values.

Traffic data on roads was obtained by own measurements because existing traffic counts were not performed at appropriate locations for use in this article. Three methods were used to collect data: manual counting, video analysis and statistical radar addition. Data on population numbers of individual municipalities were used from the national population records. Data about the distances between the municipalities and the fastest roads between them were used from the mapy.cz server.

Results confirmed that the border effect on the state border is stronger (the usual value at the border with Poland and Germany was in the range of 0,6-0,7 while at the border between the Czech regions about 0,9). On the other hand, this difference is not very large, and it can be considered as a success of cross-border cooperation. There are several exceptions to this rule. On the Czech-German border, there is an intensive commute for trade and services from the Czech Republic to Germany. In addition, through the territory of Germany, trips from Šluknov area to the agglomeration of Liberec are made. For this reason, in some 
sections the values of the indicator "intensity of spatial interactions" were around 2. In one monitored section, the border effect was very significant, it is a road that connects the capital city of Prague with regional centres in Poland across the mountain pass between the Jizera Mountains and the Krkonoše Mountains. The reason is the physical geographical conditions of the area (especially mountain relief) and the lack of comfort on the road. The unfortunate tracing of the road and its lack of quality caused the border effect to be very strong in this area.

The article confirmed that the use of gravity model for this type of task is possible. However, the condition is that the boundaries between relatively closed units where the results are not distorted by intense commuting must be used. Ideally, it should be borders of the commuting regions, which is more or less fulfilled in this article.

\section{Mgr. Emil Drápela, Ph.D.}

\section{Bc. Jan Bašta}

Katedra geografie

Technická univerzita $\mathrm{v}$ Liberci

Komenského 314/2, 46005 Liberec

E-mail: emil.drapela@tul.cz 